\title{
Textile Workers and Musculoskeletal Disorders: An Anthropo- Medical Analysis
}

\author{
Ajeet Jaiswal \\ Ajeet Jaiswal, Associate Professor, Department of Epidemiology and Public Health, Central University of Tamil \\ Nadu, Tamil Nadu, India
}

\begin{abstract}
Background: Musculoskeletal disorders are quite common work associated health problem amongst textile workers. Work-related musculoskeletaldisorders are conditions in which: The work environment and performance of work contribute significantly to the condition; and/or the condition is made worse or persists longer due to working conditions, textile workers may be denied of their fundamental basic rightsand not much importance is given to their health. Textileworkers are among the maximumsusceptible as they must have to work for lengthy hoursor duration in perilous posture.
\end{abstract}

Objectives: Present paper aims to study the anthropo-medical profile of textile workers especially in the context of musculoskeletal disorders among the textile workers.

Methodology: A cross-sectional study was conducted among 215 workers working in textile industries especially silk sarees (Banarsi saress) of district Bhadohi, Uttar Pradesh over a period of more than three months. Data collection was done after taking the ethical clearance using a semi-structured interview schedule and statistical analysis was done using SPSS.

Results: The result of this study shows that there were 48.5 percent of respondents found to be suffering from musculoskeletal disorders. The most common affected site was low back and shoulder. Most of the workers experienced that their pain occurred occasionally during heavy workload.

Conclusion: Hence, the musculoskeletal disorders were found to be associated in age group, sex and educational status. So, Health problems among textile workers are one of the areas of public health concern in the country. Reducing the work strain and providing a supportive workplace environment will have a favorable impact on work productivity.

Keywords: Musculoskeletal disorders, Textile Workers, Occupational health, Industrial Health

\section{Introduction}

Occupational health is defined as the highest degree of physical, mental and social well-being of workers in all occupations. It is the branch of healthcare which deals with all aspects of health and safety at the workplace. It lays strong emphasis on the prevention of hazards at a primary level. Occupational health is essentially preventive medicine ${ }^{1}$. Consider the demographic facts from India like total population is more than 1.3 billion; gross national per capita income (PPP) is $6490 \$$; life expectancy at birth (Male/Female) is 67.3/69.8 years; probability of dying under the age of five (per 1000 live births) is 48; total expenditure on health per capita is $75 \$$; and total expenditure on health as a percentage of GDP is $4.7^{2}$.

World Health Organization (WHO) ${ }^{3}$ expresses occupational health as all aspects of health and safety in the workplace and has a strong focus on primary prevention of hazards. The health of the workers has several determinants, including several risk factors at the workplace leading to cancers, accidents, musculoskeletal diseases, respiratory diseases, hearing loss, circulatory diseases, stress-related disorders and communicable 
diseases and others ${ }^{3}$. Textile industries especially silk sarees (Banarsi saress) and carpet are the main source of earning in district Bhadohi, accounting for over $75 \%$ of the total export earnings which employed around more than 70 percent workers in district Bhadohi ${ }^{4,5,6}$.

Musculoskeletal disorders are injuries or disorders of the muscles, nerves, tendons, joints, cartilage, and spinal discs. Work-related musculoskeletal disorders are conditions in which: The work environment and performance of work contribute significantly to the condition; and/or the condition is made worse or persists longer due to working conditions ${ }^{7}$. According to the National Institute for Occupational Safety and Health, musculoskeletal disorder is a damage that affects the musculoskeletal system of the human body, especially at bones, spinal discs, tendons, joints, ligaments, cartilage, nerves, and blood vessels. Such injuries may result due to repetitive motions, forces, and vibrations on human bodies during executing certain job activities ${ }^{8,9}$. Previous injuries, physical condition, heredity, pregnancy, lifestyle, and poor diet are the factors that contribute to the musculoskeletal symptoms ${ }^{10,11}$.

Work at a silk sarees production unit represents a complex multifaceted physical work environment with interactions among the various dimensions of workplace, inappropriate non-neutral awkward postures and rapid piece-rate production ${ }^{12}$. Musculoskeletal problems are the most common problem among silk sarees production workers or textile workers. Work-related musculoskeletal disorders are often overlooked despite being very common among textile workers. Likely explanations for the high prevalence of work-related musculoskeletal disorders include repeated movement, static posture for a long time; prolong exposure to ergonomic risk factors ${ }^{13,14}$. Work-related musculoskeletal disorders (MSD) accounts for a substantial portion of post-workday illnesses and injuries. Hence, it constitutes a major proportion of temporary or permanent disability among textile workers in many countries ${ }^{12,15,16,17 .}$

In most countries, Lower back and neck pain was the leading global cause of disability in $2015^{18,19}$. Generally, in India, the textile workers suffer from vertigo, headache, low backache, joint pain, respiratory distress, anemia, female diseases, and dysentery ${ }^{20}$. They also suffer from needle prick injury, cut injury and burn injury. The competitiveness of the different sector of textile garment industry like cloth, sarees, carpet, sarees, thread etc. in the world market is seriously affected by the ill health of the workers since ill health decreases the labor productivity to a great extent ${ }^{19,21}$. There are risks of injuries and diseases in any occupational setting where men and machine are involved. The causes of these injuries pertain to unsafe work, machine, equipment, material and/or unsafe acts. These causes of injuries and diseases present in the work and workplace may develop physical and mental stress in workers, which may result in loss of production and productivity. Moreover, thousands of toxic chemicals pose serious health threats potentially causing cancer, respiratory and skin diseases as well as adverse effects on reproductive function. Workers can be and often are exposed to hazardous chemical agents such as solvents, pesticides and metal dust $^{11,22 \text {. }}$

In India, major occupational diseases are pneumoconiosis (including silicosis, bagassosis, anthracosis and byssinosis), asbestosis, other chronic lung diseases, musculoskeletal injuries, noise-induced hearing loss, pesticide poisoning and accidents. Occupations related to construction, mining, agriculture and textile have high levels of related diseases. Occupational health professionals are the largest single group of health professionals involved in delivery of health services at the workplace. They are at the front line in helping to protect and promote the health of working population ${ }^{23}$. The concept of occupational health is new to India. It is non-existent in unorganized sectors. Even the public sector and private employers have not yet realized its importance. There is a need to create awareness about this issue amongst all stakeholders ${ }^{11}$.

There is number of lacunae in Occupational Health systemin Indialikeavery large proportion of the workforce is in the unorganized sector (more than $90 \%$ vs. less than $10 \%$ in the organized sector $)^{24}$. The occupational health management system, implementation and beneficiaries are limited largely to the organized sector, even today, after years of advancements in every field and lack of trained occupational health manpower with deficient institutions, qualification courses, training modules, infrastructure, facilities and budgetary provisions make the implementation of legislation a challenge. There is low priority and spending on public health, which is 
reflected in the field of occupational health as well ${ }^{11}$.

By clear data and information, occupational hazards and injuries is a bulging issue in national and international level and musculoskeletal disorders are one of most alarming health issues in textile industries but India has not been able to address these emergencies so $\operatorname{far}^{11,25}$. The aim of this study was to determine the prevalence and types of musculoskeletal disorders among the workers of textile industries at Bhadohi district of Uttar Pradesh, India i.e. An Anthropo-medical Analysis of musculoskeletal disorders among textile workers.

\section{Materials and Methods}

This cross-sectional study was conducted among the textile industrial workers especially working in silk sarees (Banarsi saress) production unit of district Bhadohi, Uttar Pradesh, from May to December, 2019. Considering the prevalence of musculoskeletal problems $77.6 \%$ with $95 \%$ confidence interval and a $5 \%$ margin of error, sample size for the study was calculated by using cross-sectional formula for the infinite population ${ }^{26}$. The total sample size was 215 with 1.5 design effect. Data were collected by Face to face interview with a pretested tools (Semi- structured interview schedule). English tools also translated into Hindi for the better understanding of the respondents. Prior to the data collection, proper motive behind such data collection was explained to each respondent along with oral as well as written consent were taken from each respondent of the textile Industry. Participants who were willing to give consent and they were asked for the interview. Those who refused to provide information consents and interview simply they were excluded from the study. Participants had the right to withdraw themselves from any point of the study. All interviewed questionnaires were checked for its completeness, accuracy, and consistency to exclude missing or inconsistent data. The analyzed data were presented in tables, descriptive statistics performed at the aim of interpretation of the findings. Bivariate analysis was performed to determine the association among variables. The data were analyzed by using the software SPSS version 21 .

Inclusion criteria: -1. Age-group: More than 15 years workers, 2. Apparently Textile Workers, 3. Workers of only district Bhadohi, Uttar Pradesh, 4. Subjects who voluntarily gave an Assent toparticipate in the study and, who also provided a writteninformedconsent.

Exclusion criteria: -1. Workers of other industry, 2. Subjects with earlier or permanent musculoskeletal disorder, 3. Child workers.4. History of any other acute/ chronic illness, 5. Subjects on regular medication, especially on any drugs, 6 . Workers of any other district other than Bhadohi, Uttar Pradesh, 7. Workers having less than three months of exposure.

\section{Result}

The result of the An Anthropo-medical Analysis of musculoskeletal disorders among textile workers with the aim to determine the prevalence and types of musculoskeletal disorders among the workers of textile industries at Bhadohi district of Uttar Pradesh, India were reflected in table 1,2 and 3 .

During data collection, it was observed that the ventilation and housekeeping of the industry were poor, and situated mostly in a rented house. The industries were overcrowded; the floor space for each worker was very small which is $12-16 \mathrm{sq}$. feet. The provision of lightening was not sufficient and no medical facilities, restroom, adequate latrine, canteen facilities in almost all the textile industries. 
Table 1 Distribution ofTextile Workers According to Their Socio-Economic Characteristics

\begin{tabular}{|c|c|c|c|}
\hline \multicolumn{2}{|c|}{ Socio-Economic CharacteristicsVariable } & $\begin{array}{l}\text { Number } \\
(215)\end{array}$ & Percent \\
\hline \multirow{5}{*}{$\begin{array}{l}\text { Age Group } \\
\text { (Years) }\end{array}$} & $15-24$ & 46 & 21.4 \\
\hline & $25-34$ & 120 & 55.8 \\
\hline & $35-44$ & 26 & 12.1 \\
\hline & $45-54$ & 19 & 8.8 \\
\hline & More than 54 & 4 & 1.9 \\
\hline Mean Age \pm S.D. & \multicolumn{3}{|l|}{$30.84 \pm 6.33$} \\
\hline \multirow{2}{*}{ Gender } & Male & 151 & 70.2 \\
\hline & Female & 64 & 29.8 \\
\hline \multirow{4}{*}{ Religion } & Hindu & 97 & 45.1 \\
\hline & Muslim & 75 & 34.9 \\
\hline & Christian & 28 & 13.0 \\
\hline & others & 15 & 7.0 \\
\hline \multirow{2}{*}{ Education status } & Illiterate & 96 & 44.6 \\
\hline & Literate & 119 & 55.4 \\
\hline \multirow{4}{*}{ Education level } & Can read and write & 60 & 50.4 \\
\hline & Primary level & 23 & 19.3 \\
\hline & Secondary level & 34 & 28.6 \\
\hline & Higher secondary level/above & 2 & 1.7 \\
\hline \multirow{5}{*}{ Employment Position } & Textile weaving Operator & 181 & 84.2 \\
\hline & Ironing and Finishing operation & 6 & 2.8 \\
\hline & Helper & 14 & 6.5 \\
\hline & Supervisor & 8 & 3.7 \\
\hline & Other & 6 & 2.8 \\
\hline \multirow{3}{*}{ Nature of Work } & Mild & 11 & 5.2 \\
\hline & Moderate & 187 & 86.9 \\
\hline & Heavy & 17 & 7.9 \\
\hline
\end{tabular}


Cont... Table 1 Distribution ofTextile Workers According to Their Socio-Economic Characteristics

\begin{tabular}{|c|c|c|c|}
\hline \multirow{4}{*}{ Length of Job (in years) } & $1-5$ & 178 & 82.8 \\
\hline & $6-10$ & 32 & 14.9 \\
\hline & $16-20$ & 3 & 1.4 \\
\hline & More than 20 & 2 & 1.0 \\
\hline Mean length of job \pm S.D. & \multicolumn{3}{|l|}{$3.87 \pm 3.43$} \\
\hline \multirow{3}{*}{ Working hour } & $6-8$ & 111 & 51.6 \\
\hline & $9-12$ & 76 & 35.4 \\
\hline & More than 12 & 28 & 13.0 \\
\hline Mean working hours \pm S.D. & \multicolumn{3}{|l|}{$9.45 \pm 2.14$} \\
\hline \multirow{2}{*}{ Overtime } & Yes & 104 & 48.4 \\
\hline & No & 111 & 51.6 \\
\hline \multirow{4}{*}{ Overtime per week (hours) } & $5-10$ & 7 & 6.7 \\
\hline & $11-15$ & 76 & 73.1 \\
\hline & $16-20$ & 18 & 17.3 \\
\hline & $21-25$ & 3 & 2.8 \\
\hline Mean Overtime per week \pm S.D. & \multicolumn{3}{|l|}{$12.24 \pm 2.26$} \\
\hline
\end{tabular}

Above table shows the distribution of Textile Workers according to their socio-economic characteristics. Among the total 215 respondents, the mean age of the textile workers was $30.84 \pm 6.33$ years.More than $70 \%$ of the respondent were belongs to less than 35 years old and around 20\% respondent were belongs to an age range of 35 to 54 years while only $1.95 \%$ of respondents were of more than 54 years age groups. Majority of the respondents i.e. $70.2 \%$ were male and only $29.8 \%$ were female respondents. Similarly, the around $44.6 \%$ respondents were Hindu by religion followed by $34.9 \%$ were Muslim, $13.0 \%$ were Christian while only $7 \%$ of the respondents werebelongs to other religious group like Buddhist, Jainism,Sikhism etc. Among the total respondents, 55.4\% were literate out of which $50.4 \%$ were found to be able to read and write followed by secondary level and primary level of education while only $1.7 \%$ respondent completed their higher secondary level or above and around 44.6\% respondents, were illiterate

Regarding the nature of the job of the workers, it was found that majority of the workers i.e. $84.2 \%$ work as banarasi saree weaving operator. While 2.1\% of the workers categorized under other position like machine maintenance related work. The mean working year was found to be 3.87 and standard deviation was 3.43. Majority of the respondents i.e. $82.8 \%$ had been working for 1-5 years in the same industries followed by $14.9 \%$ respondent were working for 6-10 years while only $1.0 \%$ had been working formore than 20 years. The mean working hour per day was 9.45 and standard deviation was 2.14. Among the total respondents, 51.6\% were found to be working for 6-8 hours per day. Among the total respondents, $48.4 \%$ were found to be working overtimei.e., more than eight hours. The mean overtime 
working hour per week was 12.24 while the standard deviation was \pm 2.26 . The majority of overtime workers i.e. $73.1 \%$ worked for 11-15 hours per week while only $2.8 \%$ of overtime workers worked for $21-25$ hours per week.

\section{Musculoskeletal disorders}

Table 2 Distribution of Textile Workers According to Their Characteristics of Musculoskeletal Disorders

\begin{tabular}{|l|l|l|l|}
\hline \multicolumn{2}{|l|}{ Characteristics of Musculoskeletal Disorders } & $\begin{array}{l}\text { Number } \\
(215)\end{array}$ & Percent \\
\hline \multirow{4}{*}{ Occurrence of Musculoskeletal Disorders } & Yes & 104 & 48.4 \\
\cline { 2 - 4 } & No & 111 & 51.6 \\
\hline \multirow{4}{*}{ Frequency of Pain (n=104) } & Occasionally & 85 & 81.7 \\
\cline { 2 - 4 } & Regular & 15 & 14.4 \\
\cline { 2 - 4 } & Invariably & 4 & 3.8 \\
\hline \multirow{5}{*}{ Sites of pain (n=104) } & Neck & 5 & 4.8 \\
\cline { 2 - 5 } & Waist and backbone & 69 & 66.3 \\
\cline { 2 - 4 } & Hand & 1 & 1.0 \\
\cline { 2 - 4 } & Shoulder & 28 & 26.9 \\
\hline & Legs & 1.0 \\
\hline
\end{tabular}

Table 2 depicts the distribution of Textile Workers according to their characteristics of musculoskeletal disorders. About half of the respondents i.e. $48.4 \%$ were found to be experiencing some kind of musculoskeletal discomforts. Among the total respondent experiencing musculoskeletal discomforts, the maximum respondents i.e. $66.3 \%$ had experienced waist and back pain followed by shoulder pain at $26.9 \%$ while only $2.0 \%$ of respondents had experienced hand and legs discomforts. Most of the respondents i.e. $81.7 \%$ of the respondents reported that their pain occurred occasionally during heavy workload followed by $24.4 \%$ respondents reported that their pain occurred regularly during heavy workload while only $3.8 \%$ of respondents had experienced invariably pain. The musculoskeletal disorders were found to be significantly higher in age group, gender and educational status (Table 3). 
Table 3: Statistical Demographic Relationship between Textile Workers Having Musculoskeletal Problems and Non Musculoskeletal Problems

\begin{tabular}{|c|c|c|c|c|c|c|c|}
\hline \multirow{2}{*}{\multicolumn{2}{|c|}{ Variables }} & \multicolumn{2}{|c|}{$\begin{array}{l}\text { Musculoskeletal Problems } \\
\text { (104) }\end{array}$} & \multicolumn{2}{|c|}{$\begin{array}{l}\text { Non-Musculoskeletal } \\
\text { Problems (111) }\end{array}$} & \multirow{2}{*}{$\chi^{2}$} & \multirow{2}{*}{ p-value } \\
\hline & & $\mathbf{N}$ & $\%$ & $\mathbf{N}$ & $\%$ & & \\
\hline \multirow{2}{*}{$\begin{array}{l}\text { Age Group } \\
\text { (Years) }\end{array}$} & $15-30$ & 49 & 22.79 & 69 & 32.09 & \multirow{2}{*}{5.145} & \multirow{2}{*}{$\mathrm{p}<0.05$} \\
\hline & $\begin{array}{l}31 \text { years and } \\
\text { Above }\end{array}$ & 55 & 25.58 & 42 & 19.53 & & \\
\hline \multirow{2}{*}{ Gender } & Male & 69 & 32.09 & 85 & 39.53 & \multirow{2}{*}{2.891} & \multirow{2}{*}{$\mathrm{p}<0.05$} \\
\hline & Female & 35 & 16.28 & 26 & 12.09 & & \\
\hline \multirow{2}{*}{$\begin{array}{l}\text { Education } \\
\text { Status }\end{array}$} & Illiterate & 19 & 8.83 & 12 & 5.58 & \multirow{2}{*}{6.783} & \multirow{2}{*}{$\mathrm{p}<0.05$} \\
\hline & Literate & 85 & 39.53 & 99 & 46.05 & & \\
\hline \multirow{3}{*}{$\begin{array}{l}\text { Nature of } \\
\text { Work }\end{array}$} & Mild & 5 & 2.33 & 7 & 3.26 & \multirow{3}{*}{0.309} & \multirow{3}{*}{$\mathrm{p}>0.05$} \\
\hline & Moderate & 93 & 43.26 & 97 & 45.12 & & \\
\hline & Heavy & 6 & 2.79 & 7 & 3.26 & & \\
\hline
\end{tabular}

Statistical demographic relationship between Textile Workers having musculoskeletal problems and non musculoskeletal problems showed, that the maximum i.e. $25.58 \%$ of the respondent who was experiencing some kind of musculoskeletal discomforts were belongs to age group of 31 years and above. Maximum respondent who was experiencing some kind of musculoskeletal discomforts were male (32.09\%), who is bit literate $(39.53 \%)$ and working moderate work (43.26). The musculoskeletal disorders were found to be significantly higher in age group, gender and educational status.

\section{Discussion}

The textile industries are growing without a proper plan and adequate occupational health and safety facilities. The provisions as mentioned in Labour Act $1992^{24}$ regarding health, hygiene, safety, and welfare has not been found to be implemented as desired. In this study it has been found that in the studied banarasi sarees production industries there was no adequate space for each worker and about half of the workers were working more than eight hours a day which results in decrease in the efficiency of the workers and also affects the physical and mental health of workers. In order to earn more, the garment factory workers are compelled to work for long hours in a day resulting in them to develop various musculoskeletal discomforts.

It has been found that about $77.2 \%$ of the workers were less than 35 years old and $17.3 \%$ of workers had been working for more than 5 years in the same factory. In a similar kind study conducted in Varanasi, Uttar Pradesh in 2015-16 revealed that most of the workers $62.1 \%$ were in the age group of 20-34 years and $20.5 \%$ workers had been working for more than 10 years which indicates that the young people are coming more in the production life which is important for economic development of the country ${ }^{19,31}$. This study also revealed that about $12 \%$ illiterate and $50 \%$ of the workers were literate who can only read and write. For skilled manpower and to maintain proper Occupational Safety 
and Health in the factory, education of the workers is one of the important factors, so, necessary measures, as well as motivational activity, should be undertaken to increase the educational level in the community.

In this study, it was found that about half of the respondents of the respondents were suffering from some sort of musculoskeletal disorders and the most common musculoskeletal disorders was found in the wrist and back pain. It has been reported that occupational musculoskeletal disorders are associated with physically heavy work, manual material handling, repetitive work and unsuitable work posture ${ }^{11,27,28}$.

A study conducted in Bangladesh during $2013^{29}$ and Nepal during $2020^{11}$, the respondents experiencing shoulder pain and back pain were more than $50 \%$ and there was a significant relationship between the length of job (in years) and musculoskeletal discomforts ${ }^{29,11 .}$ While in the present study there was no establishment of any statistical significance between working years and musculoskeletal discomforts. Analysis of the results of the study was significant with age group, gender, and educational status. A research conducted in Jaipur, India in 2012 revealed that in stitching section majority of workers $(55 \%)$ complained about a musculoskeletal problem which is similar to this study where the majority of the respondents working in stitching section (49.4\%) complained about musculoskeletal discomforts ${ }^{27}$. A study conducted in 2011 among female garment factory workers in Sri Lanka revealed that the majority of the respondents (63.7\%) worked as a sewing machine operator. $15.6 \%$ were found to be reporting musculoskeletal problems, the most prevalent complaint being lower back problems among the respondents ${ }^{30}$. In comparison to present study, the $58.2 \%$ of the female respondent were reported to experience musculoskeletal problems. This study gave quite similar results in terms of specific musculoskeletal discomforts of the lower back pain among the respondents. These comparisons so far show an alarming condition of workplace injuries and health hazards.

\section{Conclusion}

In this study, it is evident that half of the workers had been suffering from some kind of musculoskeletal disorders. The musculoskeletal disorders were more among the workers who worked in the weaving section. The occurrence of musculoskeletal disorders is significantly associated with age, sex, and educational status. The working space per worker was extremely inadequate. There were no medical facilities and proper toilet facilities. Almost every day the workers had to work overtime. To protect and promote the health of the workers, necessary measures should be undertaken as soon as possible to provide proper health, hygiene, and medical facilities to the workers. In order to improve the condition of workers there is a need of the acceptance of modern techniques and making machine workfriendlyshould help in improving the health conditions of textile workers. Health examinations of workers should be done on a regular basis and adequate precaution should be taken by workers to ensure safe health.

Limitations:Findings in the present study were obtained with a relatively small sample size. Future studies should be carried out on a larger and more diverse population to generalize the findings obtained here. In order to further validate the above findings, a more precise anthropometric measurement and parameters should be taken in future studies using better tools.

\section{Conflict of Interest: No conflict of interest}

\section{Source of Funding: Self}

Acknowledgments: An author is thankful to present subject and their families for their cooperation. I am especially grateful for the assistance and encouragement of Prof. A.K. Kapoor and Prof. Satwanti Kapoor and the medical professional of BHU for their help during research. An author is also thankful to Department of Anthropology, Pondicherry University and Department of Epidemiology and public Health, Central University of Tamil Nadu for providing all the basic facility to carry out the present work.

\section{References}

1. Park K. Occupational Health, Park's Textbook of Preventive and Social Medicine, 19th ed. 2007; 658.

2. http://data.worldbank.org/indicator/SH.XPD. TOTL. ZS.

3. World Health Organization (WHO). Occupational Health. 2020.

4. Census of Uttar Pradesh, Census, 2011: India 2020. 
Publication Division. 2011; 23-33

5. Jaiswal A. A Study of The Occupational Health Function Among Female Textile Workers" Int J of Socio and Anthro (IJSA) 2011; 3 (3): 109-114.

6. Jaiswal A. A Case Control Study Among Carpet Thread Factory Workers inUttar Pradesh, India: Occupational Injury and Its Deteriorating Factors. Glo J of Hum Soci Scie, Hist and Anthro. 2012; 12 (10): 23-30.

7. Bernard BP. U.S. Musculoskeletal Disorders and Workplace Factors: A Critical Review of Epidemiologic Evidence for Work-Related Musculoskeletal Disorders of The Neck, Upper Extremity, And Lower Back. Dept of Health and Hum Serv. Centers for Dise Cont and Preve, Nati Insti of Occu Safe and Health.1997; 97-141.

8. Jaiswal A. Job Stress and Occupational Accident among Blue- Collar Workers of India: An Anthropological Insight. Int J of Multid Res in Soci Scie. 2016; 2(1): 1-11.

9. Jaiswal A. Study the Relationship between fatigue, sleepiness and Accidents among workers of Indian Weaving Industries. IntJ of scientific Footprints. 2014; 2 (2): 18-30.

10. Orhan K., Asad A. M. Work-Related Musculoskeletal Disorders, Work-related Musculoskeletal Disorders, Introductory Chapter. Orhan Korhan, IntechOpen, 2019.

11. Shah S, Shakya A, Maharjan PL. Musculoskeletal Disorders Among the Garment's Workers in Rupandehi District, Nepal. MOJ Public Health. 2020;9(4):117-120

12. Saha T.K., Dasgupta A, Butt A. Health Status of Workers Engaged in the Small-scale Garment Industry: How Healthy are They? Ind J of commu Medi. 2010; 35(1):179-182.

13. Ghosh T. Occupational Health and Hazards Among Health Care Workers. Int Jof Occu Safety and Health. 2013; 3(1):1- 4.

14. Jaiswal A. Low Back Pain and Work-Related Risk Factors among Drivers of Pondicherry. Int $\mathrm{J}$ of scientific Footprints. 2013; 1 (2): 7-16.

15. Rahman S, Siddiquee S. Musculoskeletal Disorder Among the Garment Workers: A Major WorkRelated Health Problem In A Leading Garment
Industry of Bangladesh. Occu and Medi Health. 2018; 75(2).

16. Jaiswal A. An Anthropological and Medical Analysis on Respiratory Problem and Worker's Working Condition" IntJ of Res in Socio and Anthro. 2015 (1): 1: 18-28.

17. Jaiswal A. Occupational Health Risk and Blood Pressure among Salt Workers of Marakkanam District of Tamil Nadu. Int $\mathbf{J}$ of Res in Socio and Anthro. 2016; (2): 1:36-47.

18. Vos T, Allen C, Arora M. Global, Regional, And National Incidence, Prevalence and Years Lived with Disability for Diseases and Injuries, (19902015)- A Systematic Analysis for The Global Burden of Disease Study 2015. Lancet. 2016; 388(10053):1545-1602.

19. Jaiswal A. A Cross-Sectional Study on Industrial Health Hazards among Garment Factories Workers of Tamil Nadu. Asian Man, An Int J, 2018; (12): 1: 29-36.

20. Jaiswal, A. An Occupational Hazard and Public Health Investigation among the Fabric Workers of India. Asian Man, An Int J. 2016; (10): 2: 241-246.

21. Gupta RD, Nag S, Datta D. Occupational Health Hazards Among Workers in Garment Factories in Bangladesh: A Cross-Sectional Study. Developing Country Studies. 2015;5(5):90-98.

22. Sudha B, Meenaxi T. Occupational Health Hazards in Textiles Industry. Asian J of Home Sci. 2014; 9(1):267-271.

23. Nagpal AS. Occupational Health Nursing, Health Action. July 2017; 30(7): 22

24. Jaiswal A. Occupational Injuries related to Sleepiness in Indian Traditional Industries. Hum Bio Review. 2012 1(3): 248-267.

25. Jaiswal A. Assessment of Respiratory Disorders among workers in Cigarette Industry. Hum BioReview. 2013, 2(4): 294-305.

26. Ravichandran SP, Shah PB. Health Problems and Risk Factors Prevailing Among Garment Workers in Tirupur, Tamil Nadu. Int J of Commu Medicine and Pub Health. 2018;5(6):2400-2405.

27. Mehta R. Major Health Risk Factors Prevailing in Garment Manufacturing Units of Jaipur. J of Ergonomics. 2012;2(2):1-3. 
28. Smedley J, Egger P, Cooper C. Manual Handling Activities and Risk of Low Back Pain in Nurses. Occu and Envi Medicine. 1995;52(3):160-163.

29. Samaddar K.K. Occupational Health andSafety Management inRMG Sector ofBangladesh. International journal of scientific technology research. 2016; 5(12):176-193.
30. Lombardo SR, Vijitha de Silva P, Lipscomb HJ. Musculoskeletal Symptoms Among Female Garment Factory Workers inSri Lanka. Int $\mathrm{J}$ of Occu and Envi health. 2012;18(3):210-219.

31. Saramon S. A Study on Exposure Related Health Problems in Textile Industry. J of Occu Medi \&Health Affair. 2014;2(3):67. 